Revista Bioética

\title{
PESQUISA
}

\section{Social pressures and reactions of adolescent drug users in an outpatient clinic}

Ana Luiza Portela Bittencourt ${ }^{1}$, Lucas França Garcia ${ }^{2}$, José Roberto Goldim ${ }^{3}$

1. Departamento de Ensino, Instituto Federal de Educação, Ciência e Tecnologia Sul-Rio-Grandense (IFSul), Gravataí/RS, Brasil. 2. Programa de Pós-Graduação em Promoção da Saúde, Centro Universitário de Maringá (Unicesumar), Maringá/PR, Brasil. 3. Programa de Pós-Graduação em Ciências Médicas, Universidade Federal do Rio Grande do Sul (UFRGS), Porto Alegre/RS, Brasil.

\begin{abstract}
Coercive measures and social pressures may affect patients and the treatment for substance abuse disorder. This study analyzes the reactions of adolescents who use psychoactive substances to potentially coercive situations and its effects during treatment. The collected data were analyzed with mixed methods. Results show the prevalence of informal social pressures (48.1\%). We classified patients' reactions as acceptance (17.5\%), resistance (31.6\%), and lack of motivation (14\%). Resistance and lack of motivation can affect the treatment and patients' autonomy. The use of mixed methods was essential to analyze the medical records regarding senses and meanings and allowed us to quantify and compare the findings with the literature and the qualitative data. Keywords: Coercion. Substance-related disorders. Adolescent. Methods.
\end{abstract}

\section{Resumo}

Pressões sociais e reações de adolescentes usuários de drogas em tratamento ambulatorial

Medidas coercivas e pressões sociais podem afetar tanto pacientes como o tratamento para transtorno por uso de substâncias psicoativas. Este estudo analisa as reações de adolescentes usuários de substâncias psicoativas a situações potencialmente coercivas durante o tratamento. Os dados coletados foram analisados usando métodos mistos. Pressões sociais informais $(48,1 \%)$ foram o tipo de pressão mais frequente. As reações dos pacientes foram classificadas como aceitação $(17,5 \%)$, resistência $(31,6 \%)$ e falta de motivação (14\%). Resistência e falta de motivação podem prejudicar o tratamento e a autonomia dos pacientes. $O$ uso de métodos mistos foi essencial para analisar os prontuários em relação a sentidos e significados, e nos permitiu quantificar e comparar os achados com a literatura e com dados qualitativos.

Palavras-chave: Coerção. Transtornos relacionados ao uso de substâncias. Adolescente. Métodos.

\section{Resumen}

Presiones sociales y reacciones de los adolescentes consumidores de drogas en tratamiento ambulatorio Las medidas coercitivas y las presiones sociales pueden afectar a los pacientes y al tratamiento de los trastornos por consumo de sustancias psicoactivas. En este estudio se analizan las reacciones de los adolescentes consumidores de sustancias psicoactivas ante situaciones potencialmente coercitivas durante el tratamiento. Los datos reunidos se analizaron con métodos mixtos. Las presiones sociales informales $(48,1 \%)$ fueron el tipo de presión más frecuente. Las reacciones de los pacientes se clasificaron como aceptación (17,5\%), resistencia $(31,6 \%)$ y falta de motivación (14\%). La resistencia y la falta de motivación pueden perjudicar el tratamiento y la autonomía de los pacientes. El uso de métodos mixtos fue esencial para analizar los registros médicos en relación con los significados y las direcciones, y nos permitió cuantificar y comparar los hallazgos con la literatura y los datos cualitativos.

Palabras clave: Coerción. Trastornos relacionados con sustancias. Adolescente. Métodos. 
The Brazilian model of mental health care has undergone important changes since the 1990s. Treatments became more focused on community care, breaking away from the hospital-based model and emphasizing humane treatment, social reintegration, and service appraisal to assure the rights of people with mental illness ${ }^{1}$. Based on this new approach to treating mental disorders, Psychosocial Care Centers (Caps) were established in the country.

Conceived to provide community care services, these centers allow patients to receive follow-up locally and help them restore social connections by encouraging reintegration into the various social roles they once played ${ }^{2}$. These centers also received priority in the care of people with severe and persistent mental illnesses of different age groups, including those with substance use disorders (SUD) ${ }^{3}$. Although their implementation represents an enormous advance in community-based mental health care, there has been much criticism regarding the care provided ${ }^{4-6}$.

Psychoactive substance use along with other typical adolescence aspects and a poor and inefficient service network contribute to characterize adolescents as a highly vulnerable group ${ }^{7-10}$. This is particularly alarming as early psychoactive substance use anticipates consequences and losses associated with this issue, such as health problems, legal penalties, family and social conflicts, dropping out of school, and feelings of anxiety and guilt ${ }^{11-13}$.

Caring for drug users is currently one of the greatest challenges for public mental health care managers and professionals ${ }^{14}$. The stigma of aggressiveness and character defect surrounding substance users boosts support for legal pressure to compel individuals into treatment ${ }^{15}$. A risky approach in providing health services, since it potentially hinders understanding the patients' needs, resulting in a poor and coercive treatment ${ }^{16}$.

Perceive addictive behaviors as a burden, either in the public health context as in social and economic terms, renders pressures from different sources an integral part of the process of seeking addiction treatment ${ }^{17-19}$. As a way to deal with such costs, society uses different control strategies to ensure that substance users receive treatment ${ }^{20}$.

Social pressures are modes of social control, coercive or not ${ }^{18,19,21}$, classified into three types: legal (from judicial institutions); formal (from formal organizations, such as employers, schools, and social welfare programs); and informal (from family, friends, or acquaintances) ${ }^{17-19}$. For some authors, coercion and perceived coercion are synonyms, meaning that patients feel a lack of influence, control, freedom, or choice regarding treatment ${ }^{22-24}$.

Despite a lack of consensus on the effectiveness of social pressure in compelling individuals into treatment, Lidz and collaborators ${ }^{25}$ state that feeling coerced negatively affects the patient. This leads to poor adherence to treatment and dropping out ${ }^{18,26-28}$, loss of trust in caregivers, alienation, avoidance of treatment ${ }^{25}$, and lower patient satisfaction concerning new hospital admissions ${ }^{29}$. Identifying treatment-related ethical challenges helps to improve the quality of mental health care, to reduce the use of coercive strategies, and to increase patient's participation in the treatment ${ }^{30}$, in particular when dealing with young people, who suffer greater objective pressure and are more likely to report feeling coerced ${ }^{31}$.

Strategies such as enhanced communication between staff and patients, treatment negotiation, and explanation may help to improve how patients experience the admission process ${ }^{32}$. Identifying how adolescent patients react to pressures, building an empathetic rapport, reduces the social stigma associated with addiction treatment and the effect of social pressures, providing patients with more positive and beneficial treatment experience. This study aimed to analyze how adolescents who use psychoactive substances react when facing potential coercive situations during their treatment at a Psychosocial Care Center for Children and Adolescents (Capsia).

\section{Method}

This study is part of the research project "The trajectory of adolescent users of psychoactive substances at Capsia," approved by the Research Ethics Committee of Hospital de Clínicas de Porto Alegre. We conducted a cross-sectional study with 229 medical records of adolescent substance users receiving treatment at Capsia (Santa Cruz do Sul, Rio Grande do Sul, Brazil) from 2002 to 2012, describing their biopsychosocial profile and identifying risk factors for early drug use initiation ${ }^{33}$.

\section{Data collection}

Data were collected from medical records until data saturation ${ }^{34,35}$. The numbers (previously assigned by Capsia) of all the 229 medical records were organized into a spreadsheet and arranged in 
ascending order. A total of 23 (10\%) medical records were randomly selected by sequential sampling ${ }^{35}$ one medical record was randomly selected by drawing lots among the first 10 numbers; then, based on this sequence, one was selected from every 10 records and analyzed by two of the authors.

The study subjects were identified by the letter " $\mathrm{S}$ " to maintain anonymity, followed by the corresponding number in the spreadsheet, the letter indicating the patient's gender ( $M$, male; $F$, female) and age. The MacArthur Perceived Coercion Scale ${ }^{36}$ helped to identify any entry or record information of potentially coercive situations, where behaviors or events suggested: 1) reduced freedom of choice regarding treatment; 2 ) being treated was not the patient's choice; 3) seeking treatment was not their idea; 4) lack of patient's control over treatment decisions; and 5) seeking treatment rested more on an external influence than on their choice.

Other situations during treatment included: police involvement, compulsory hospitalization or admission, use of drug containment, treatment opposition (resistance, escape, irritation), and social or parental pressure to enter treatment, as shows the literature on the subject ${ }^{32,37-39}$. Social pressures were then classified according to referral source (legal, formal, and informal) ${ }^{18,19}$, and passages describing patients' reactions to these coercive situations were identified in the medical records. Analysis and description of the quantitative data were performed in SPSS version 18.0 and QSR NVivo 10 , and the qualitative data by content analysis ${ }^{40}$.

\section{Results and discussion}

This study analyzed the medical records of 23 adolescents undergoing treatment at Capsia. Most patients were male (87\%), $69.6 \%$ of them had committed offenses, and reported using marijuana $(34.8 \%)$, cocaine $(34.8 \%)$, crack $(30.4 \%)$, alcohol $(26.1 \%)$, tobacco $(17.4 \%)$, glue $(13 \%)$, and ecstasy (4.3\%). Similar data were found in a previous study analyzing the medical records of all adolescents in treatment at Capsia during the same period ${ }^{33}$. Therefore, the data collected are representative of the general population treated at this facility.

The analysis found 66 notes written by the staff, comprising 81 passages describing different social pressures the patients experienced. Only four records had no account of social pressure. The prevalence of informal social pressure (48.1\%) (Table 1) is consistent with the study by Urbanoski ${ }^{18}$, suggesting that family and friends often exert pressure on treatment-seeking choice. In the study conducted by Room ${ }^{41}$, alcohol and drug users identified family and friends as the most common sources of pressure to enter treatment, indicating that informal pressure precedes formal pressure.

Table 1. Social pressures identified in 66 notes from 23 medical records of adolescents undergoing treatment at Capsia (Santa Cruz do Sul, Rio Grande do Sul, Brazil, 2002-2012)

\begin{tabular}{l|c}
\multicolumn{1}{c|}{$\begin{array}{c}\text { Type of social } \\
\text { pressure }\end{array}$} & Recording frequency \\
\hline Informal & $39(48.1 \%)$ \\
\hline Formal & $25(30.9 \%)$ \\
\hline Legal & $17(21.0 \%)$ \\
\hline Total & $\mathbf{8 1 ( 1 0 0 . 0 \% )}$ \\
\hline
\end{tabular}

This prevalence of informal over formal and legal pressures contrast with most studies ${ }^{42}$ and indicates that these pressures must be addressed and considered during the treatment process. In previous studies, participants identified as voluntary patients also reported some degree of perceived coercion ${ }^{18,42,43}$.

Of the 19 medical records comprising social pressures, 18 had 44 notes written by the staff with 57 passages describing patient's reactions (Table 2), which were grouped into nine different categories: 1) willingness to be treated; 2) treatment acceptance; 3) lack of motivation; 4) resistance; 5) denial of drug use; 6) anger; 7) omnipotence; 8) escape; and 9) resignation.

Table 2. Reactions of patients identified in 44 notes from 19 medical records of adolescents undergoing treatment at Capsia (Santa Cruz do Sul, Rio Grande do Sul, Brazil, 2002-2012)

\begin{tabular}{l|c}
\multicolumn{1}{c|}{ Type of reaction } & Recording frequency \\
\hline Omnipotence & $1(1.8 \%)$ \\
\hline Willingness to be treated & $2(3.5 \%)$ \\
\hline Anger & $3(5.3 \%)$ \\
\hline Escape [real] & $3(5.3 \%)$ \\
\hline Denial of use & $6(10.5 \%)$ \\
\hline Resignation & $6(10.5 \%)$ \\
\hline Lack of motivation & $8(14.0 \%)$ \\
\hline Treatment acceptance & $10(17.5 \%)$ \\
\hline Resistance & $18(31.6 \%)$ \\
\hline Total & $\mathbf{5 7}(\mathbf{1 0 0 . 0 \% )}$ \\
\hline
\end{tabular}


The prevalence of resistance $(31.6 \%)$ and treatment acceptance $(17.5 \%)$ are consistent with the study by Lorem, Hem, and Molewijk ${ }^{37}$, who, after interviewing psychiatric inpatients, classified their reactions to coercive measures as agreeing and accepting, fighting or resisting, and resignation. However, their study focused on investigating patients' moral evaluation of previously experienced coercion rather than identifying and associating the pressures with the reactions they triggered.

We must emphasize that recording the reactions in the moment of pressure implies different understanding of these experiences than if they had been reported later, since different factors affect the patients' perception of coercion: the institutionalization period, feelings of gratitude, internalization of experiences ${ }^{44}$, personal characteristics ${ }^{22}$, understanding of the severity of the condition, and the degree of pressure experienced ${ }^{18}$. Nevertheless, to reflect on coercive strategies and their uses helps to prevent possible future damage to both patient and treatment, especially considering that these patients lack further opportunities to reevaluate their experiences due to poor adherence of psychoactive substance users to treatment ${ }^{11,45}$.

The passages describing patients' reactions resulted in 76 associations with social pressures, since one reaction could correspond to more than one pressure (Table 3). Resistance was most commonly associated with informal pressure (33.3\%), also being frequent in formal (26.9\%) and legal pressures (30\%). Lack of motivation (30.7\%) and resignation (25\%) were most associated with formal and legal pressures, respectively. Omnipotence was linked only with legal pressure, while willingness to be treated was associated only with informal pressure, and denial of drug use was related with both types.

These findings show that enforcing forms of control rather than eliciting immediate positive responses from these patients increased their perception of coercion, resulting in the absence of a significant association between positive reactions and the types of pressure. It also indicates that these patients felt coerced by different sources to enter treatment. The qualitative data analysis dealt with the three most frequent reaction categories in the quantitative analysis of the observation notes (Table 2): resistance, lack of motivation, and treatment acceptance.
Table 3. Association between patients' reactions and different types of social pressures identified in 18 medical records of adolescents undergoing treatment at Capsia (Santa Cruz do Sul, Rio Grande do Sul, Brazil, 2002-2012)

\begin{tabular}{l|c|c|c}
\multicolumn{1}{c|}{$\begin{array}{c}\text { Type of } \\
\text { reaction }\end{array}$} & $\begin{array}{c}\text { Informal } \\
\text { pressure }\end{array}$ & $\begin{array}{c}\text { Formal } \\
\text { pressure }\end{array}$ & $\begin{array}{c}\text { Legal } \\
\text { pressure }\end{array}$ \\
\hline $\begin{array}{l}\text { Willingness to } \\
\text { be treated }\end{array}$ & $2(6.7 \%)$ & $0(0.0 \%)$ & $0(0.0 \%)$ \\
\hline $\begin{array}{l}\text { Treatment } \\
\text { acceptance }\end{array}$ & $5(16.7 \%)$ & $6(23.1 \%)$ & $1(5.0 \%)$ \\
\hline $\begin{array}{l}\text { Lack of } \\
\text { motivation }\end{array}$ & $3(10.0 \%)$ & $8(30.8 \%)$ & $3(15.0 \%)$ \\
\hline Resignation & $2(6.7 \%)$ & $1(3.8 \%)$ & $5(25.0 \%)$ \\
\hline Resistance & $10(33.3 \%)$ & $7(26.9 \%)$ & $6(30.0 \%)$ \\
\hline Denial of use & $4(13.3 \%)$ & $0(0.0 \%)$ & $2(10.0 \%)$ \\
\hline Escape [real] & $1(3.3 \%)$ & $3(11.5 \%)$ & $1(5.0 \%)$ \\
\hline Omnipotence & $0(0.0 \%)$ & $0(0.0 \%)$ & $1(5.0 \%)$ \\
\hline Anger & $3(10.0 \%)$ & $1(3.8 \%)$ & $1(5.0 \%)$ \\
\hline Total & $\begin{array}{c}\mathbf{3 0} \\
\mathbf{( 1 0 0 . 0 \% )}\end{array}$ & $\begin{array}{c}\mathbf{2 6} \\
\mathbf{1 0 0 . 0 \% )}\end{array}$ & $\begin{array}{r}\mathbf{2 0} \\
\mathbf{( 1 0 0 . 0 \% )}\end{array}$ \\
\hline
\end{tabular}

\section{Resistance}

Resistance means refusing to receive the proposed treatment, being associated with all three forms of social pressure and the most frequently reported by the patients: he arrives at the Capsia accompanied by a protection officer without the presence of a parent or guardian. The mother quarreled with her son and refused to accompany him to the health care facility. The adolescent reports having been admitted to several clinics, but none worked. He does not want to be admitted and does not want to stop using drugs. He says he uses drugs because he wants to (excerpt from the report on S133M17). This passage exemplifies a legal social pressure in action: the patient who refused admission was taken to the facility by a protection officer, a staff member of the Child and Youth Court responsible for search and seizure warrants, as defined by the Court of Justice of the State of Rio Grande do Sul ${ }^{46}$.

In this case, the adolescent was reluctant to accept hospitalization and seemed to regard the hospital treatment as inefficient, since several previous hospitalizations have not yielded positive results for him. His unwillingness to be admitted and decision to continue using drugs were not respected. The pressure used in this case seems justified by the perceived legal understanding, criticized by Wertheimer ${ }^{47}$, of mental illness as a prerogative for the use of force, ignoring the 
individual's decisions. In this sense, his decision to continue using drugs was probably understood as "influenced" by the illness.

Informal pressure exerted in a context of conflict - between the adolescent and his mother, for example - also results in resistance reactions when patients no longer see a family member as someone who can demand something from them. Considering this association, Wertheimer ${ }^{47}$ proposes that coercion varies according to the coercive agent's moral force: when the individual under pressure recognizes the coercive agent's right to make demands, the likelihood of feeling coerced decreases. In situations of poor or frayed family relationships, the coercive agent is no longer seen as someone who can impose or propose treatment. Patient S173M13 expresses the same situation of refusal and family conflict, though in a more subtle manner:

Situation 1: He joins the group for the first time. She is worried about her son's situation, who left home and school. He has no limits, disrespects her, and sleeps in a bathroom in the back of their house. He stole all his grandmother's belongings. Today he agreed to join the group (on S173M13's mother).

Situation 2: First day in the group meeting. He was reluctant to come, kept silent and held his head down during the entire meeting (report on S173M13).

Accounts of social damage, linked to psychoactive substance abuse, such as dropping out of school, theft, and exposure to degrading situations (sleeping in the bathroom, for instance), seem to explain the informal pressure. According to Wild, Roberts, and Cooper ${ }^{20}$, society often uses control strategies to treat substance abusers because they represent a social and economic burden. Bittencourt, França, and Goldim ${ }^{33}$ described a similar situation when associating social and health problems with the referral of male adolescents with multiple offenses for treatment at Capsia. Another issue associated with resistance is the avoidance of treatment through escape:

Situation 1: A call from the shelter informing that [S123M17] was sent there by the judge until his hospital admittance for detoxification. (...) I call the hospital and get a bed for today. The transfer will occur in the afternoon, and a Capsia employee will accompany the patient (report on S123M17).
Situation 2: A person from the hospital calls to report that [S123M17] escaped. He was found by police officers and taken back to the hospital. He keeps saying he will run away again and stay in the hospital for as long as he wants (report on S123M17).

These excerpts show two interactions between the Capsia staff and other patient care facilities. First, the adolescent suffers legal pressure to enter treatment; then, after admission, the hospital nurse (formal pressure) calls to inform the Capsia staff (formal pressure) of his escape. The patient shows clear opposition to the situation: he cannot refuse to participate in the hospital treatment, so he escapes and is recaptured by the police, and continues threatening to escape again. In this sense, coercion may involve different social pressures:

She spent the night at home and slept well, according to her mother. She arrives at Capsia showing resistance, refuses to enter the consultation room, states that she no longer wants to be hospitalized and wants to continue using drugs. She physically and verbally assaults her mother, says she will "smash everything" at the hospital, and escapes. I write requesting a search warrant for tomorrow (report on S153F16).

Here the patient's resistance and later escape is motivated by her mother's informal pressure and by the health professional's formal pressure, when requesting judicial intervention. In addition, we have an angry reaction, represented by the physical and verbal assault and threats to "smash everything" at the hospital.

Lorem, Hem, and Molewijk ${ }^{37}$ grouped fighting and resisting reactions into the same category, as both are associated with the patients' lack of control over the treatment and loss of autonomy: struggle and resistance are common in situations where the patient perceives coercion as a form of threat. This may not be the case here, but the pressures may have been interpreted in this way by the patients.

Resistance to care seems to represent a struggle for self-determination, in which the reaffirmation of the desire to continue using drugs is employed to escape treatment. When it loses effectiveness, patients use other available defenses: escape, aggression, and silence. Marked by the presence of physical, verbal, and possibly psychological abuse, resistance questions the effectiveness of such care, especially when the patients show clear opposition. 


\section{Lack of motivation}

Motivating patients to engage in treatment is one of the greatest challenges in mental health care. According to the self-determination theory ${ }^{48}$, motivation depends on personal, social, and environmental factors. A person may show personal interest in performing an activity (intrinsic motivation), may perform an activity without engaging (amotivation), or may do it aiming at the result (extrinsic motivation).

Thus, lack of motivation means poorly integrating and internalizing the importance of treatment, sought as a result of external pressure. Such behavior corresponds to extrinsic motivation regulated by external factors, where the individual enters treatment to relieve these pressures or escape possible sanctions ${ }^{18}$.

According to Urbanoski ${ }^{18}$, most patients undergoing treatment for substance use disorders drop out because care became meaningless. This lack of motivation to engage in treatment, similarly to resistance, affects the whole process, mainly in terms of adherence: the mother has kept him locked at home since Sunday (...) to prevent drug use. She asked the Child Protective Services [CPS] for help. (...) The patient is sleepy and apathetic. He remained silent during the interview (report on S93M13).

Here, both the mother (informal pressure), who locked the adolescent at home to prevent him from using drugs, and the Child Protective Services (formal pressure) sought to engage the adolescent into treatment, without results. Despite no further information on the patient, his silence during the interview indicates a lack of personal interest in the treatment. The report on S43M14 is similar: he and his mother came for the initial interview accompanied by a CPS agent, who did not participate in the interview (he only brought the referral papers). The mother reports her interest in continuing with the treatment; [S43M14] only seems to be complying with the court order.

The patient, brought in by his mother and the CPS agent, also experienced the legal pressure of a court order. The healthcare team noticed the patient's disinterest in the treatment, highlighting that the mother is the one willing her son to be treated in the health care facility. The observation note included in S13M17's medical record is even clearer:

The patient says that he was absent last week because he lacks the motivation to engage in treatment and believes he can consume alcohol moderately. He came today because "CPS made me." He explains that "I have to come," otherwise "the judge sends me to (...)". He seems annoyed and unmotivated to continue treatment. He asks if 2 or 3 weeks is enough to meet the CPS and judge's requirement (report on $\mathrm{S} 13 \mathrm{M} 17$ ).

This report shows the patient's complete lack of motivation, and that he is there only due to external pressures - once they cease, he intends to stop the treatment.

All these attempts show that engaging in treatment is often an extrinsic motivation regulated by multiple external factors such as pressure from friends and family, the legal system, and other formal sources ${ }^{17}$. According to Ryan and Deci ${ }^{48}$, this shows that seeking treatment is not a selfdetermined act, as behaviors motivated solely by external factors reflect poor individual autonomy, feelings of alienation, and loss of control.

\section{Acceptance}

In our study, acceptance of treatment and proposed interventions relied on the relationship established between patient and coercive agent.

The patient arrives with his mother. He says that it is hard to stop drinking. He drank every day last week. He drinks shots in the morning to stop shaking and at night to fall asleep. He says that he talked to his girlfriend over the weekend and she said that, if he quits drinking, she will come back to him. This week he will attend a Narcotics Anonymous meeting because he found out it is close to his home. The mother says that the family cannot handle the situation, her married children do not visit her anymore because they do not want to see the problem. The mother feels exhausted. She wants him to be hospitalized (report on S3M16).

A set of informal pressures - his girlfriend willingness to resume their romantic relationship, the potential to restore a good family relationship and the patient's awareness on the severity of alcohol addiction may have facilitated his positive reaction to pressure. Another patient (S153F16) perceived her friends' pressure to stop using crack as positive, indicating her willingness to stop using psychoactive substances.

A study by Goodman, Peterson-Badali, and Henderson ${ }^{49}$ showed that family members, romantic partners, and friends often pressure patients to seek treatment and reduce psychoactive substance use. As friendship and romantic relationships are essential in adulthood, such individuals can more 
easily negotiate aspects of drug use, frequently evoking feelings of shame and guil ${ }^{50}$. These feelings correspond to an intermediate level of motivation, in which entering treatment respond to conflicting intrapersonal feelings such as guilt and anxiety ${ }^{17}$.

Patients also accept treatment after pressure by professionals from different institutions. S193M11, for example, sought treatment after a referral from the school: he has been using marijuana for about two months. He was referred because was caught smoking at school. He has a good relationship with classmates and teachers and has good grades. Good family relationship (...). Behavior during the interview: collaborative, good insight (report on S193M11).

In this case, the substance user not only accepts the treatment but actively participates in it a positive attitude influenced by his good relationship with different social groups. Schenker and Minayo ${ }^{12}$ state that family and school are crucial in enhancing resilience and promoting critical reflection on drug abuse; but they must be established in a way to strengthen ties of trust. Wei and collaborators ${ }^{51}$ also indicate social bonds as factors for motivating change and helping adolescents to maintain abstinence.

However, accepting treatment does not mean the patient understands the process as important or necessary: he arrives with his grandmother. He says he came looking for help because of alcohol use. He says he will get married and become a father soon, so he wants to "get his life back on track." He says he came because the social worker asked him to and that he had no desire to come spontaneously (report on S13M17).

S13M17 admits seeking treatment only after external pressure (social worker), and the report shows how fundamental his positive relationship with the coercive agent was for accepting treatment. On this issue, Lorem, Hem and Molewijk ${ }^{37}$ showed that pressure was more easily accepted when the patient trusted the coercive agent. These findings are consistent with the research by Rugkåsa and collaborators ${ }^{52}$, who indicate that a trusting relationship between patients and health professionals is a prerequisite for negotiating treatment or influencing the patient to engage in the process. For the authors, a good relationship must value the patient's concerns and priorities.

Goodman and collaborators ${ }^{50}$ state that young people who regard themselves as having greater responsibility toward others are more likely to recognize their addiction as problematic and to seek change. In these cases, patients perceive these relationships not as coercive or treatmentrelated, but as self-determined and justified by the losses involved. In the S13M17's case, acceptance is associated with the idea that he must "get his life back on track" for his unborn child and family.

A good relationship with friends, family, health professionals, and other individuals who are part of the patient's social network appears to evoke these individuals' commitment, leading to greater acceptance of interventions, facilitating engagement in treatment, and providing opportunities for reflecting about their lives. This is ultimately a personal decision, but acceptance may occur through the patients' perception that coercive agents have the right to require them to undergo addiction treatment.

\section{Final considerations}

Data analysis showed that social pressures are common in the treatment of adolescents who use psychoactive substances, mainly the prevalence of informal pressures, a finding consistent with the literature ${ }^{18,19,31,41,49}$. Vulnerability conditions observed in these young patients, characterized by substance use, dropping out of school, offenses, and contentious family relationships, are often used to justify different forms of coercion.

Although acceptance was one of the most frequent reactions, negative reactions prevailed when the association between reactions and social pressures was analyzed, giving way to resistance, lack of motivation, and resignation. Resistance appeared in the face of conflicting relationships with the coercive agent and when the patient's wishes were disregarded or disrespected. Lack of motivation, in turn, emerged from seeking treatment solely because of the experienced pressure, resulting in low treatment adherence.

A good relationship between patients and coercive agents stood out when analyzing acceptance reactions. This relationship allowed a less confrontational environment and greater engagement by providing opportunities to reflect on the need for addiction treatment.

This study allows a better understanding of these patients' experiences by showing that social pressures affect these individuals in different ways. The importance of a good relationship between patients and caregivers, and between patients and other individuals of their social circle, emphasizes 
that health professionals should act alongside them to manage conflicts and deal with these adolescents.

Researchers and addiction-treatment institutions should give further attention to informal and formal pressures, as they affect patient and treatment, considering that patients' reactions when facing different potentially coercive situations are mostly negative.

Basing the study on the medical records was the appropriate choice, as these documents represent a great source of information, but the sole use of external elements identified as potentially coercive posed its limitations. Recorded by different staff members, the data may have presented disparities, incompleteness, and omissions. The medical record review also precluded access to the patient's account of the events and how they experienced them. Further studies including direct interviews with psychoactive substance users are important for a better understanding of how social pressures affect them, as it allow patients to recount their experiences and reasons for seeking treatment.

For their financial support, we would like to thank the Coordination for the Improvement of Higher Education Personnel (Capes) and the Productivity Scholarship Program of the Cesumar Institute for Science, Technology, and Innovation (Iceti).

\section{References}

1. Guimarães AN, Fogaça MM, Borba LO, Paes MR, Larocca LM, Maftum MA. O tratamento ao portador de transtorno mental: um diálogo com a legislação federal brasileira (1935-2001). Texto Contexto Enferm [Internet]. 2010 [acesso 2 abr 2018];19(2):274-82. DOI: 10.1590/ S0104-07072010000200008

2. Brasil. Ministério da Saúde. Saúde mental no SUS: os centros de atenção psicossocial [Internet]. Brasília: Ministério da Saúde; 2004 [acesso 5 abr 2019]. Disponível: https://bit.ly/3bDzAOb

3. Rabelo AR, Mattos AA, Coutinho DM, Pereira N. Um manual para o Caps: centro de atenção psicossocial. 2a ed. Salvador: Edufba; 2006.

4. Machado V, Santos MA. O tratamento extra-hospitalar em saúde mental na perspectiva do paciente reinternado. Psicol Estud [Internet]. 2013 [acesso 2 abr 2018];18(4):701-12. DOI: 10.1590/S1413-73722013000400012

5. Brasil. Ministério da Saúde. Saúde Mental em Dados 12 [Internet]. Brasília: Ministério da Saúde; 2015. Disponível: https://bit.ly/3cJT2Jb

6. Brasil. Ministério da Saúde. Reforma psiquiátrica e política de saúde mental no Brasil. In: Conferência Regional de Reforma dos Serviços de Saúde Mental: 15 anos depois de Caracas; 7-10 nov 2005; Brasília. Brasília: Opas; 2005.

7. Brasil. Ministério da Saúde. Diretrizes nacionais para a atenção integral à saúde de adolescentes e jovens na promoção, proteção e recuperação da saúde. Brasília: Ministério da Saúde; 2010.

8. Frankenburg FR. Brain-robbers: how alcohol, cocaine, nicotine, and opiates have changed human history. Westport: Praeger; 2014.

9. Outeiral JO. Adolescer: estudos revisados sobre adolescência. Rio de Janeiro: Revinter; 2003.

10. Silva MAI, Mello FCM, Mello DF, Ferriani MGC, Sampaio JMC, Oliveira WA. Vulnerabilidade na saúde do adolescente: questões contemporâneas. Ciênc Saúde Coletiva [Internet]. 2014 [acesso 2 abr 2018];19(2):619-27. DOI: 10.1590/1413-81232014192.22312012

11. Brasil. Ministério da Saúde. A política do Ministério da Saúde para a atenção integral a usuários de álcool e outras drogas. Brasília: Ministério da Saúde; 2003.

12. Schenker M, Minayo MCS. Fatores de risco e de proteção para o uso de drogas na adolescência. Ciênc Saúde Coletiva [Internet]. 2005 [acesso 2 abr 2018];10(3):707-17. DOI: 10.1590/S1413-81232005000300027

13. Vasters GP, Pillon SC. Drugs use by adolescents and their perceptions about specialized treatment adherence and dropout. Rev Latinoam Enferm [Internet]. 2011 [acesso 2 abr 2018];19(2):317-24. DOI: 10.1590/S0104-11692011000200013

14. Pitta AMF. Um balanço da reforma psiquiátrica brasileira: instituições, atores e políticas. Ciênc Saúde Coletiva [Internet]. 2011 [acesso 2 abr 2018];16(12):4579-89. DOI: 10.1590/ S1413-81232011001300002

15. Watson AC, Corrigan PW, Angell B. What motivates public support for legally mandated mental health treatment? Soc Work Res [Internet]. 2005 [acesso 2 abr 2018];29(2):87-94. DOI: $10.1093 / \mathrm{swr} / 29.2 .87$

16. Soares RG, Silveira PS, Martins LF, Gomide HP, Lopes TM, Ronzani TM. Distância social dos profissionais de saúde em relação à dependência de substâncias psicoativas. Estud Psicol [Internet]. 2011 [acesso 2 abr 2018];16(1):91-8. DOI: 10.1590/S1413-294X2011000100012

17. Urbanoski KA, Wild TC. Assessing self-determined motivation for addiction treatment: validity of the treatment entry questionnaire. J Subst Abuse Treat [Internet]. 2012 [acesso 2 abr 2018];43(1):70-9. DOI: $10.1016 /$ j.jsat.2011.10.025 
18. Urbanoski KA. A theory-based analysis of coercion in addiction treatment [tese] [Internet]. Toronto: University of Toronto; 2010 [acesso 2 abr 2018]. Disponível: https://bit.ly/2xOJZIm

19. Wild TC. Social control and coercion in addiction treatment: towards evidence-based policy and practice. Addict [Internet]. 2006 [acesso 2 abr 2018];101(1):40-9. DOI: 10.1111/j.1360-0443.2005.01268.x

20. Wild TC, Roberts AB, Cooper EL. Compulsory substance abuse treatment: an overview of recent findings and issues. Eur Addict Res [Internet]. 2002 [acesso 2 abr 2018];8(2):84-93. DOI: 10.1159/000052059

21. Wild TC. Compulsory substance-user treatment and harm reduction: a critical analysis. Subst Use Misuse [Internet]. 1999 [acesso 2 abr 2018];34(1):83-102. DOI: 10.3109/10826089909035637

22. Hiday VA, Swartz MS, Swanson J, Wagner HR. Patient perceptions of coercion in mental hospital admission. Int J Law Psychiatry [Internet]. 1997 [acesso 2 abr 2018];20(2):227-41. DOI: 10.1016/ s0160-2527(97)00004-6

23. Hoge SK, Lidz CW, Eisenberg M, Gardner W, Monahan J, Mulvey E et al. Perceptions of coercion in the admission of voluntary and involuntary psychiatric patients. Int J Law Psychiatry [Internet]. 1997 [acesso 2 abr 2018];20(2):167-81. DOI: 10.1016/S0160-2527(97)00001-0

24. Hoge SK, Lidz CW, Eisenberg M, Monahan J, Bennett N, Gardner W et al. Family, clinician, and patient perceptions of coercion in mental hospital admission: a comparative study. Int J Law Psychiatry [Internet]. 1998 [acesso 2 abr 2018];21(2):131-46. DOI: 10.1016/S0160-2527(98)00002-8

25. Lidz CW, Mulvey EP, Hoge SK, Kirsch BL, Monahan J, Eisenberg M et al. Factual sources of psychiatric patients' perceptions of coercion in the hospital admission process. Am J Psychiatry [Internet]. 1998 [acesso 2 abr 2018];155(9):1254-60. DOI: 10.1176/ajp.155.9.1254

26. Monahan J, Hoge SK, Lidz C, Roth LH, Bennett N, Gardner W, Mulvey E. Coercion and commitment: understanding involuntary mental hospital admission. Int J Law Psychiatry [Internet]. 1995 [acesso 2 abr 2018];18(3):249-63. DOI: 10.1016/0160-2527(95)00010-f

27. Nicholson RA, Ekenstam C, Norwood S. Coercion and the outcome of psychiatric hospitalization. Int J Law Psychiatry [Internet]. 1996 [acesso 2 abr 2018];19(2):201-17. DOI: 10.1016/0160-2527(96)00005-2

28. Taborda JGV, Baptista JP, Gomes DAR, Nogueira L, Chaves MLF. Perception of coercion in psychiatric and nonpsychiatric (medical and surgical) inpatients. Int J Law Psychiatry [Internet]. 2004 [acesso 2 abr 2018];27(2):179-92. DOI: 10.1016/j.ijlp.2004.01.008

29. Strauss JL, Zervakis JB, Stechuchak KM, Olsen MK, Swanson J, Swartz MS et al. Adverse impact of coercive treatments on psychiatric inpatients' satisfaction with care. Community Ment Health J [Internet]. 2013 [acesso 2 abr 2018];49(4):457-65. DOI: 10.1007/s10597-012-9539-5

30. Hem MH, Molewijk B, Pedersen R. Ethical challenges in connection with the use of coercion: a focus group study of health care personnel in mental health care. BMC Med Ethics [Internet]. 2014 [acesso 2 abr 2018];15(1):82. DOI: 10.1186/1472-6939-15-82

31. Wolfe S, Kay-Lambkin F, Bowman J, Childs S. To enforce or engage: the relationship between coercion, treatment motivation and therapeutic alliance within community-based drug and alcohol clients. Addict Behav [Internet]. 2013 [acesso 2 abr 2018];38(5):2187-95. DOI: 10.1016/j.addbeh.2013.01.017

32. Katsakou C, Bowers L, Amos HT, Morriss R, Rose D, Wykes T, Priebe S. Coercion and treatment satisfaction among involuntary patients. Psychiatr Serv [Internet]. 2010 [acesso $2 \mathrm{abr}$ 2018];61(3):286-92. DOI: 10.1176/appi.ps.61.3.286

33. Bittencourt ALP, França LG, Goldim JR. Adolescência vulnerável: fatores biopsicossociais relacionados ao uso de drogas. Rev. bioét. (Impr.) [Internet]. 2015 [acesso 2 abr 2018];23(2):311-9. DOI: $10.1590 / 1983-80422015232070$

34. Turato ER. Tratado da metodologia da pesquisa clínico-qualitativa: construção teórico-epistemológica, discussão comparada e aplicação nas áreas da saúde e humanas. 6ạ ed. Petrópolis: Vozes; 2013.

35. Shelley SI. Research methods in nursing and health. Boston: Little Brown; 1984.

36. Gardner W, Hoge SK, Bennett N, Roth LH, Lidz CW, Monahan J, Mulvey EP. Two scales for measuring patients' perceptions for coercion during mental hospital admission. Behav Sci Law [Internet]. 1993 [acesso 2 abr 2018];11(3):307-21. DOI: 10.1002/bsl.2370110308

37. Lorem GF, Hem MH, Molewijk B. Good coercion: patients' moral evaluation of coercion in mental health care. Int J Ment Health Nurs [Internet]. 2015 [acesso 2 abr 2018];24(3):231-40. DOI: $10.1111 /$ inm.12106

38. Mielau J, Altunbay J, Gallinat J, Heinz A, Bermpohl F, Lehmann A, Montag C. Subjective experience of coercion in psychiatric care: a study comparing the attitudes of patients and healthy volunteers towards coercive methods and their justification. Eur Arch Psychiatry Clin Neurosci [Internet]. 2016 [acesso 2 abr 2018];266(4):337-47. DOI: 10.1007/s00406-015-0598-9

39. Valenti E, Banks C, Calcedo-Barba A, Bensimon CM, Hoffmann KM, Pelto-Piri V et al. Informal coercion in psychiatry: a focus group study of attitudes and experiences of mental health professionals in ten countries. Soc Psychiatry Psychiatr Epidemiol [Internet]. 2015 [acesso 2 abr 2018];50(8):1297-308. DOI: 10.1007/s00127-015-1032-3

40. Bardin L. Análise de conteúdo. São Paulo: Edições 70; 2011.

41. Room R. The U.S. general population's experiences of responding to alcohol problems. Br J Addict [Internet]. 1989 [acesso 2 abr 2018];84(11):1291-304. DOI: 10.1111/j.1360-0443.1989.tb00731.x 
42. Wild TC, Newton-Taylor B, Alletto R. Perceived coercion among clients entering substance abuse treatment: structural and psychological determinants. Addict Behav [Internet]. 1998 [acesso 2 abr 2018];23(1):81-95. DOI: 10.1016/S0306-4603(97)00034-8

43. O'Donoghue B, Roche E, Shannon S, Lyne J, Madigan K, Feeney L. Perceived coercion in voluntary hospital admission. Psychiatry Res [Internet]. 2014 [acesso 2 abr 2018];215(1):120-6. DOI: 10.1016/j.psychres.2013.10.016

44. Bittencourt ALP, Quintana AM, Velho MTAC, Goldim JR, Wottrich LAF, Cherer EQ. A voz do paciente: por que ele se sente coagido? Psicol Estud [Internet]. 2013 [acesso 2 abr 2018];18(1):93-101. DOI: $10.1590 /$ S1413-73722013000100010

45. Laranjeira R. Tratamento da dependência do crack: as bases e os mitos. In: Ribeiro M, Laranjeira R, organizadores. O tratamento do usuário de crack. São Paulo: Casa Leitura Médica; 2010. p. 15-23.

46. Rio Grande do Sul. Corregedoria-Geral da Justiça. Consolidação normativa judicial: atualizada até o Provimento no 18/2012-CGJ (outubro/2012) [Internet]. Porto Alegre: Corregedoria-Geral da Justiça; 2012 [acesso 5 abr 2019]. Disponível: https://bit.ly/3eTVgHz

47. Wertheimer A. A philosophical examination of coercion for mental health issues. Behav Sci Law [Internet]. 1993 [acesso 2 abr 2018];11(3):239-58. DOI: 10.1002/bsl.2370110303

48. Ryan RM, Deci EL. Self-determination theory and the facilitation of intrinsic motivation, social development, and well-being. Am Psychol [Internet]. 2000 [acesso 2 abr 2018];55(1):68-78. DOI: $10.1037 / 0003-066 X .55 .1 .68$

49. Goodman I, Peterson-Badali M, Henderson J. Understanding motivation for substance use treatment: the role of social pressure during the transition to adulthood. Addict Behav [Internet]. 2011 [acesso 2 abr 2018];36(6):660-8. DOI: 10.1016/j.addbeh.2011.01.011

50. Goodman I, Henderson J, Peterson-Badali M, Goldstein AL. The relationship between psychosocial features of emerging adulthood and substance use change motivation in youth. J Subst Abuse Treat [Internet]. 2015 [acesso 2 abr 2018];52:58-66. DOI: 10.1016/j.jsat.2014.12.004

51. Wei CC, Heckman BD, Gay J, Weeks J. Correlates of motivation to change in adolescents completing residential substance use treatment. J Subst Abuse Treat [Internet]. 2011 [acesso 2 abr 2018];40(3):272-80. DOI: 10.1016/j.jsat.2010.11.014

52. Rugkåsa J, Canvin K, Sinclair J, Sulman A, Burns T. Trust, deals and authority: community mental health professionals' experiences of influencing reluctant patients. Community Ment Health J [Internet]. 2014 [acesso 2 abr 2018];50(8):886-95. DOI: 10.1007/s10597-014-9720-0

\section{Participation of the authors}

Ana Luiza Portela Bittencourt designed the study with José Roberto Goldim, collected data, and wrote the manuscript with Lucas França Garcia. All authors analyzed the data and participated in the manuscript's critical review.

\section{Correspondence}

Ana Luiza Portela Bittencourt - Instituto Federal de Educação, Ciência e Tecnologia Sul-Rio-Grandense. Departamento de Ensino. Campus Gravataí. Rua Men de Sá, 800, Bom Sucesso CEP 94135-300. Gravataí/RS, Brasil.

Ana Luiza Portela Bittencourt - PhD - alportelab@gmail.com

(iD) 0000-0002-2333-720X

Lucas França Garcia - PhD - lucasfgarcia@gmail.com

(iD) 0000-0002-5815-6150

José Roberto Goldim - PhD - jrgoldim@gmail.com

(iD) $0000-0003-2127-6594$ 